\title{
A newborn with neck mass
}

\author{
Recém-nascido com massa cervical
}

Rita Calado Pereira ${ }^{1}$, Laura Martins Barrosoํㅜ, Maria José Mendes ${ }^{1}$, Isabel Fernandes Joaquim¹, Helder Ornelas ${ }^{1}$

\begin{abstract}
Congenital goiter is a rare cause of neonatal neck mass and may result from a fetal defectin synthesis of thyroxine, or administration of antithyroid drugs or iodides during pregnancy. The thyroid dysfunction often accompanies it. This report describes a case of a male term newborn with congenital goiter and primary hypothyroidism. Hormonal replacement treatment was started leading to normal levels of free thyroxine and triiodothyronine. In face of a maternal negative investigation, dyshormonogenesis was considered to be the most probable cause of hypothyroidism.
\end{abstract}

Keywords: Infant, newborn; Goiter; Congenital hypothyroidism; Case reports

\section{RESUMO}

0 bócio congênito é uma causa rara de massa cervical no recémnascido podendo resultar de um defeito na síntese de tiroxina pelo feto, ou administração de antitiroidianos ou substâncias contendo iodo durante a gravidez. Na maioria das vezes, acompanha-se de disfunção tireoidiana. É descrito o caso de um recém-nascido a termo, de sexo masculino, com bócio congênito e hipotireoidismo primário. Foi iniciada terapia hormonal de reposição com normalização dos níveis de tiroxina e triiodotironina. Como a investigação materna foi negativa, disormonogênese foi considerada a causa mais provável do hipotiroidismo.

Descritores: Recém-nascido; Bócio; Hipotireoidismo congênito; Relatos de casos

\section{INTRODUCTION}

Congenital goiter (CG) is a rare cause of neonatal neck mass and may result from maternal ingestion of antithyroid drugs or goitrogens, transplacental passage of maternal antibodies or inborn errors of thyroid hormone production (dyshormonogenesis). Other rarer causes include activating mutations of the TSH receptor (congenital nonautoimmune hyperthyroidism), activating mutations of the $\mathrm{G}$ protein alpha subunit (McCune-Albright syndrome), thyroid hemiagenesis and thyroid tumors. Even in hereditary forms, goiter and thyroid dysfunction that often accompanies it, may not be evident at birth ${ }^{(1)}$. Dyshormonogenesis of the thyroid system represents about 10 to $20 \%$ of all cases of congenital hypothyroidism, and most neonates would exhibit a relatively large goiter ${ }^{(2)}$.

\section{CASE REPORT}

A full-term male neonate, first child of nonconsanguineous parents, was admitted to the Neonatology Unit for weak weeping, feeding difficulty, hypoglycemia and an enlarged anterior cervical mass present at birth (Figure 1). The examination on admission revealed mild hypotonicity in addition to central swelling in the neck. The mass felt soft, mobile, non-cystic, without associated inflammatory signs and no bruit was audible. The remainder of the examination was unremarkable.

There was no record of thyroid disease or deafness in the family. The newborn's mother was a healthy young woman, who had an uncomplicated pregnancy, with no history of alcohol, illicit drugs, use of thiourea derivatives/ antithyroid drugs (propiltiouracil, methimazole, carbimazole), iodine-rich drugs (amiodarone, antiasthmatic agents, expectorants), lithium or any other goitrogens during gestation. She had no goiter and her thyroid function was normal with negative thyroid antibodies.

\footnotetext{
Study carried out at Hospital do Espírito Santo - EPE, Evora, Portugal

${ }^{1}$ Hospital do Espírito Santo - EPE, Evora, Portugal.

Corresponding author: Rita Margarida Calado Pereira - Rua Ladislau Patrício, 8, 1B - Lumiar - CEP 1750-136 - Lisboa, Portugal

Received on Sep 24, 2010 - Accepted on Feb 11, 2011

The authors declare there is no conflict of interest.
} 


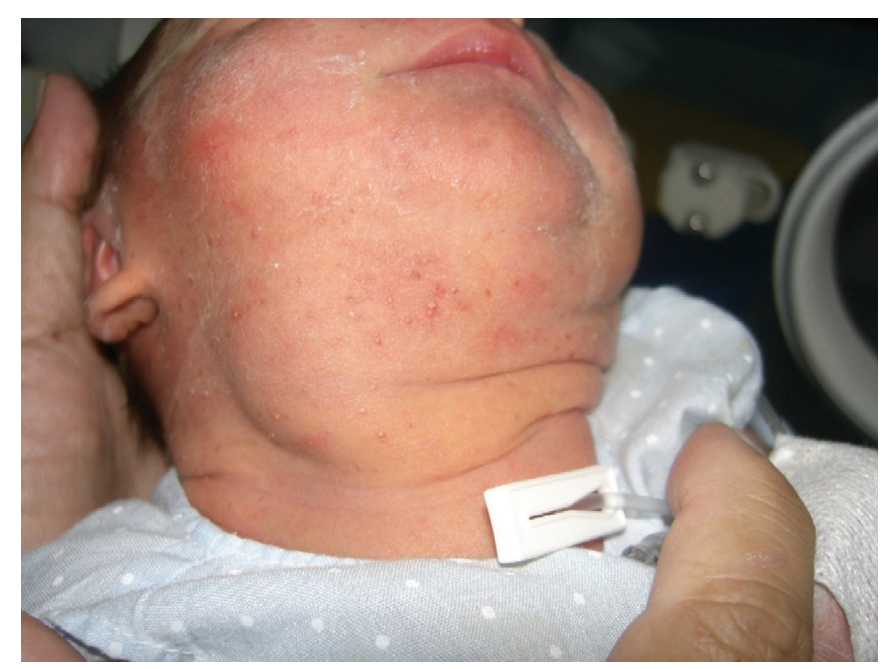

Figure 1. Enlarged anterior neck mass ( $2^{\text {nd }}$ day of life).

An ultrasonography was performed showing a marked diffuse enlargement of the thyroid gland (Figure 2). The findings of low serum free thyroxine $(\mathrm{FT} 4=1.7 \mu \mathrm{g} / \mathrm{dL})$ and high serum levels of thyroid stimulating hormone $(\mathrm{TSH}>150 \mu \mathrm{UI} / \mathrm{mL})$ confirmed the diagnosis of primary hypothyroidism. Hormonal replacement treatment with L-thyroxine (25 $\mu \mathrm{g} /$ day) was immediately started. Three days later, having a serum TSH of $16.6 \mu \mathrm{UI} / \mathrm{mL}$, the child was able to eat, had good sucking and feeding tolerance.

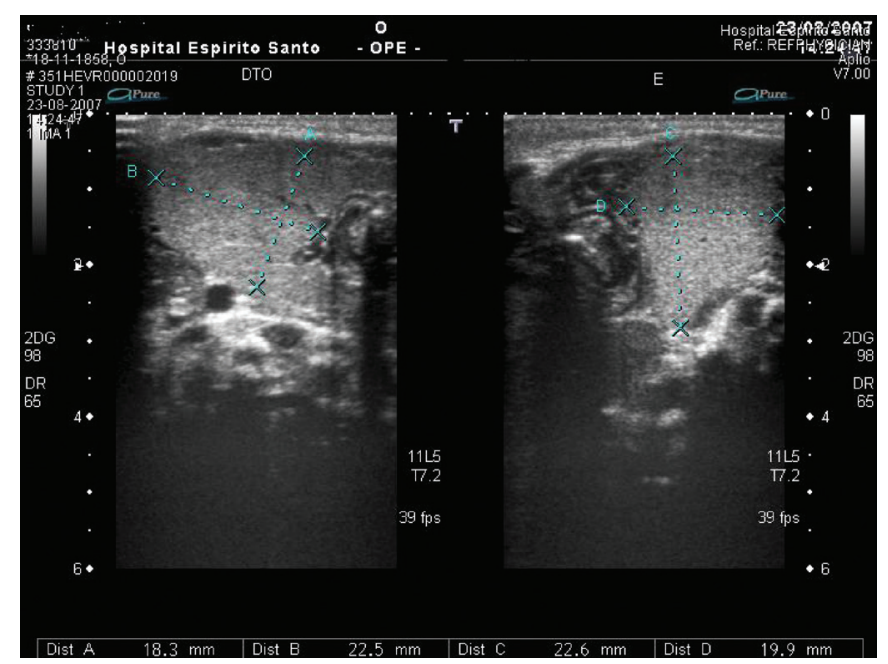

Figure 2. Neck ultrasonography - diffuse enlargement of the thyroid gland.

By the $12^{\text {th }}$ day of hospitalization, it could be noticed the reduction of the goiter size along with muscular tonus improvement. Its course remained thereafter relatively uneventful. After 2 weeks of treatment, his free thyroxine and triiodothyronine levels normalized and his thyroid stimulating hormone decreased to almost normal values. Therapeutic adjustment was performed.
The child was discharged on the $18^{\text {th }}$ day of life with thyroid volume barely palpable, no changes in physical and neurological examination and normal neonatal hearing screening. He has continued to receive treatment with L-thyroxine and has been followed-up in the Pediatric Department of the Hospital Espírito Santo de Évora (EPE), with the support of a consultant pediatric endocrinologist.

His evolution seemed to be favorable with appropriate growth and psychomotor development.

\section{DISCUSSION}

Although the diagnosis of neonatal neck mass can be made on both clinical grounds and different imaging modalities available, sometimes recognizing a mass in this region may not be easy due to the difficulty of examining the neck of neonates and to the insidious growth of some lesions that remain unnoticed.

Neck masses in newborns may be differentiated by their location and include the following: cystic hygroma; lymphangioma that is the most common lymphatic malformation in children, typically presented as a painless, transilluminated, soft mass located superior to the clavicle; branchial cleft cysts, palpated along the anterior margin of the sternocleidomastoid muscle; hematomas, which that may be the cause of masses in the lower portion of the neck; and finally thyroglossal duct cyst or enlarged thyroid that may present with a midline mass ${ }^{(3)}$. Isolated palpable cervical lymph nodes, up to $12 \mathrm{~mm}$ in diameter, are common in healthy newborns. However, lymphadenopathy may also result from congenital infection ${ }^{(3)}$.

The clinical findings presenting with goiter vary from asymptomatic to enlarged thyroid volume causing stridor, cyanosis and respiratory distress by airway obstruction that can be a serious emergency.

While sporadic CG is a rare clinical entity, thiourea drugs and other goitrogens administered during pregnancy can induce thyroid hyperplasia in the fetus causing goiter in infants of treated mothers. Women with chronic autoimmune thyroiditis or Graves disease may also produce antibodies that cross the placenta, resulting in fetal and neonatal goiter and thyroid dysfunction, depending upon the type of antibody ${ }^{(1)}$. Among other etiologies for CG are colloid goiter of iodine deficiency (less common in iodine-sufficient areas of the world) and a variety of inborn errors of thyroid hormone production. These defects are inherited as autosomal recessive traits. All result in varying degrees of hypothyroidism, and may be detected by newborn screening (4).

The prevalence of congenital hypothyroidism, an important preventable cause of mental retardation, 
is approximately 1:4,000 births. Abnormal thyroid development (dysgenesis or agenesis) or a defect in thyroid hormonogenesis are the most frequent causes of permanent congenital hypothyroidism. Less commonly, the altered neonatal thyroid function is transient, attributable to the transplacental passage of maternal medication, maternal blocking antibodies (typically resolving in 3 to 6 months), or iodine deficiency or excess $^{(5)}$.

The presence of goiter in a newborn with primary hypothyroidism suggests transient hypothyroidism or an intrinsic defect in thyroid hormone synthesis ${ }^{(6)}$.

In the present case, patient's mother was a healthy young woman, with no goiter. Her thyroid function tests were normal and there were no circulating autoantibodies. She was taking no medications. Therefore, dyshormonogenesis was considered to be the most probable cause of the hypothyroidism.

In a newborn with a defect in thyroid hormone synthesis, a hearing screening must be performed to rule out Pendred syndrome (iodide organification defect and deafness) ${ }^{(7)}$.

The overall goals of treatment are to assure normal growth and development and psychometric outcome similar to genetic potential, by restoring the serum $\mathrm{T} 4$ concentration as rapidly as possible to a normal range followed by continued clinical and biochemical euthyroidism $^{(8)}$. In this case, diagnosis and treatment of hypothyroidism occurred even earlier than most of other reported cases in which the diagnosis of congenital hypothyroidism was made by the usual screening.

Occasionally this disorder may be identified prenatally with the chance of prenatal treatment of such cases by injecting T4 into the amniotic fluid. Thus it is important to highlight the role of strict ultrasound monitoring during future pregnancies in order to detect fetal goiter.

Compliance to treatment plan, periodic followup care and adjustment of therapy are essential pieces for a good outcome. Genetic counseling is also recommended.

Goiters in newborn infants are not seen frequently but all pediatricians who deal with neonates should be in a position to recognize the syndrome, understand its cause and prognosis and to advise therapy ${ }^{(9)}$.

\section{REFERENCES}

1. La Franchi S, Kirkland JL, Ross D, Hoppin A, Mulder J. Congenital and acquired goiter in children. UpToDate, Waltham, MA, 2010.

2. Medeiros-Neto GA, Stanbury JB. Inherited disorders of the thyroid system. Boca Raton, FL: CRC Press; 1994

3. Southgate WM, Pittard WB. Classification and physical examination of the newborn infant. In: Klaus $\mathrm{MH}$, Fanaroff $\mathrm{AA}$, editors. Care of the high-risk neonate. 5th ed. Philadelphia: WB Saunders; 2001. p. 100.

4. Muir A, Daneman D, Daneman A, Ehrlich R. Thyroid scanning, ultrasound and serum thyroglobulin in determining the origin of congenital hypothiroidism. Am J Dis Child. 1988;142(2):214-6.

5. American Academy of Pediatrics, Rose SR; Section on Endocrinology and Committee on Genetics, American Thyroid Association, Brown RS; Public Health Committee, Lawson Wilkins Pediatric Endocrine Society, Foley T, Kaplowitz PB, Kaye Cl, Sundararajan S, Varma SK. Update of newborn screening and therapy for congenital hypothyroidism. Pediatrics. 2006;117(6): 2290-303

6. Felner El. A newborn with a goiter and thyroid dyshormonogenesis. J MaternalFetal \& Neonatal Med. 2002;12(3):207-8.

7. Everett LA, Glaser B, Beck JC, Idol JR, Buchs A, Heyman M, et al. Pendred syndrome is caused by mutations in a putative sulphate transporter gene (PDS). Nature Genet. 1997;17(3):411-22.

8. LaFranchi S. Treatment and prognosis of congenital hypothyroidism. In: Rose BD, editors. UpToDate. Waltham, MA; 2010.

9. Crawford JD. Goiters in childhood. Pediatrics. 1956;17(3):437-41. 